\title{
Article
}

\section{Is art a "good" mediator in a Science Festival?}

\author{
Fabienne Crettaz von Roten, Olivier Moeschler
}

This paper relates to a special case of science-society mediation set up during the Science et Cité festival 2005. This national event took place in about twenty cities in Switzerland to promote a closer cooperation between science and society via art (theatre, music, dance, exhibitions, cinema, etc.), in order to reach the population at large. Results on the profile of the public, the role played by the cultural institutions involved, the motives of the visitors and the role of art in the science-society dialogue show that the goals aimed at by the festival's organisers were only partially reached. Moreover, the analyses shed light on the complex relation between art, science and society in public understanding of science activities.

\section{Context}

Science and technology have become one of the most important variable in the development of society a major force of production and of most individuals' well-being -, but the public has become less and less trustful of scientific authority and expresses reservations toward certain scientific developments. In this context, as we face increasingly complex and determining scientific and technological choices, the communication between science and society has become an important issue, for both the scientific community and the authorities. ${ }^{1}$

From the mid 80's, a certain number of activities of scientific communication (public lectures, demonstrations, debates, laboratory open day) can be observed in the Anglo-Saxon countries. Increasingly more modern and ingenious techniques are deployed to achieve this goal, such as science cafés, science festivals, science shops or science by mail. The first modern science festival took place in 1988 in Edinburgh ${ }^{2}$ and, nowadays, many different kinds of science festivals are organized on the international, national, regional and local levels.

Joined together under the label "PUS", 3 these activities initially aimed at informing the population about scientific issues, ${ }^{4}$ were then aimed at "breaking down barriers" between the scientific community and the public to create a "dialogue" between the two, even to make the concerned groups take part locally in the knowledge production process. ${ }^{6}$ Over the years, groups less interested in science, which must therefore be reached as a priority, were identified: women, young people and less educated people.

Various forms of mediation between science and society were proposed, and art was sometimes used in this context. Historically, the transmission of scientific themes by artistic performances goes back a long way: it has been done primarily via exhibitions, performance-related conferences, theatre plays as well as literature. ${ }^{7}$ Art is now increasingly used in order to design new science centres, renovate existing ones and conceive exhibitions. ${ }^{8}$

However, the role of art in this context is ambivalent. If art has been used on several occasions in the past to communicate scientific themes, ${ }^{9}$ sociological studies on cultural practices regularly point out the distinctive role of $\operatorname{art}^{10}$ and the exclusive connotation of culture and its consumption. ${ }^{11}$ And if, like some have suggested, art can generally favour a trigger in the comprehension of scientific themes ${ }^{12}$ and activate processes of participation and dialogue, ${ }^{13}$ the relations between artists and scientists are often marked by a "misunderstanding", as pointed out by Jean-Marc Lévy-Leblond. ${ }^{14}$ The latter sees certainly a "shared philosophical background" between the two fields and considers that science, through art, "is humanised" and "enters the world of the sensitive and culture", in the broad sense. But there is a difference, according to him, between the team work of the scientists, generally supported by the authorities, and the more solitary, often non-recognised, of the artists, as well as between first-person plural on the scientists' side and first-person singular on the other side. This often leads less to a dialogue 
between science and art than to a "juxtaposition". According to another author, experience suggests that the greatest impact is on the creation of new art "rather than shifting science from its current ways of working". ${ }^{15}$

Is art a good mediator in the relation established between science and society in a science festival? We will analyse this question from a concrete case: the Science et Cité festival 2005 organised in Switzerland, whose slogan was "A Festival of the Sciences and Arts": the aim was to bring science closer to the people via art and artists. Did this festival, at the same time scientific and artistic, succeed in attracting a large audience? How was the relation between science, art and society on this occasion? And which general lessons can one draw from the study of this particular case?

\section{The Science et Cité festival and its evaluation}

Organised in May 2005 in collaboration between the Science et Cité Foundation and the international Brainweek, the second edition of the Science et Cité festival ${ }^{16}$ aimed at exploring the theme of "conscience" (in French meaning both consciousness and conscience), playing with the double meaning of the word, i.e. neuropsychological and ethical or moral.

The idea of the initiators of the event was to communicate with the population via art and artists, i.e. to invite various scientific disciplines (biology, medicine, psychology, theology, etc.) but also artistic fields (theatre, exhibitions, all styles of music, dance, performances, etc.) to reflect on the following general question: "What are the respective contributions of the sciences and arts to the formation of consciousness and the perception of what is consciousness?" Scientists and artists were invited "to express and share their opinions and ideas" and in particular to "speak about their ethics". ${ }^{17}$ Practically, the arts should allow to reach people who would not be reached by a pure scientific event. The setting of the 2005 festival - for which the set-up largely counted on bottom up-initiatives - was very wide: more than 500 events were held during ten days in not-less-than 19 cities throughout the country. Among the artistic contributions, there were existing artistic works related with the theme ${ }^{18}$ and original works created for the Science et Cité festival. ${ }^{19}$

The evaluation was carried out by the authors on a mandate of the Foundation Science et Cité. In two large German-speaking cities (Basel and Zurich), one large French-speaking city (Lausanne) and two average cities in each linguistic area of the country (Aarau and Neuchâtel), 2667 visitors were questioned by forty interviewers at the exit of more than 120 events of the festival. ${ }^{20}$

\section{Results}

In order to explore the role of art in the science-society mediation, we will look more closely at four aspects: 1. the profile of the visitors of the 2005 Science et Cité festival; 2. the role of the cultural institutions; 3. the visitors' motives for taking part in the event, in particular in terms of their interest for art or science; 4 . the role of art in the dialogue between science and society.

\section{The profile of the visitors of the festival: a cultivated public}

This event was intended to attract a large audience and in particular the groups traditionally identified as being less interested in science: women, young people and less educated people.

Table 1 shows that among the audience, women are clearly over-represented compared to their proportion in the national population (57\% against $51 \%$ ). Moreover, the average age is higher than in the population (43 against 40 years) and, especially, also higher than at the time of the 2001 Science et Cité festival which, being more centred on public spaces, made it possible to attract a younger public, with an average age of 37 years. $^{21}$ In terms of education, it should be noted that the people with tertiary education represent six people out of ten in the public, a much higher rate than in the Swiss population, which is less than $20 \%$. 


\begin{tabular}{|c|c|c|c|}
\hline & & Festival 2005 & $\begin{array}{r}\text { Sw iss population } \\
(2004)\end{array}$ \\
\hline Sex & $\begin{array}{l}\text { Men } \\
\text { Women }\end{array}$ & $\begin{array}{l}42.6 \\
57.4\end{array}$ & $\begin{array}{l}48.9 \\
51.1\end{array}$ \\
\hline \multirow[t]{2}{*}{ Age } & $\begin{array}{l}17 \text { years and below } \\
18-24 \text { years } \\
25-39 \text { years } \\
40-54 \text { years } \\
55 \text { years and above }\end{array}$ & $\begin{array}{r}4.3 \\
13.5 \\
29.3 \\
29.5 \\
23.3\end{array}$ & $\begin{array}{r}19.8 \\
8.3 \\
21.8 \\
22.4 \\
27.8\end{array}$ \\
\hline & Average & 43 years & 40 years \\
\hline Education & $\begin{array}{l}\text { Elem entary school } \\
\text { Vocational training } \\
\text { Gym nasium } \\
\text { High profes sional s. } \\
\text { University }\end{array}$ & $\begin{array}{r}4.9 \\
13.5 \\
9.5 \\
12.7 \\
59.4\end{array}$ & $\begin{array}{r}18.3 \\
45.8 \\
7.7 \\
10.1 \\
18.1\end{array}$ \\
\hline \multicolumn{2}{|l|}{ Total } & 100.0 & 100.0 \\
\hline \multicolumn{4}{|c|}{$n(2005)=2667 ; n$ (Swiss pop. 2004$)=4126$} \\
\hline
\end{tabular}

Table 1. Profile of the public of the 2005 Science et Cité festival (in \%).

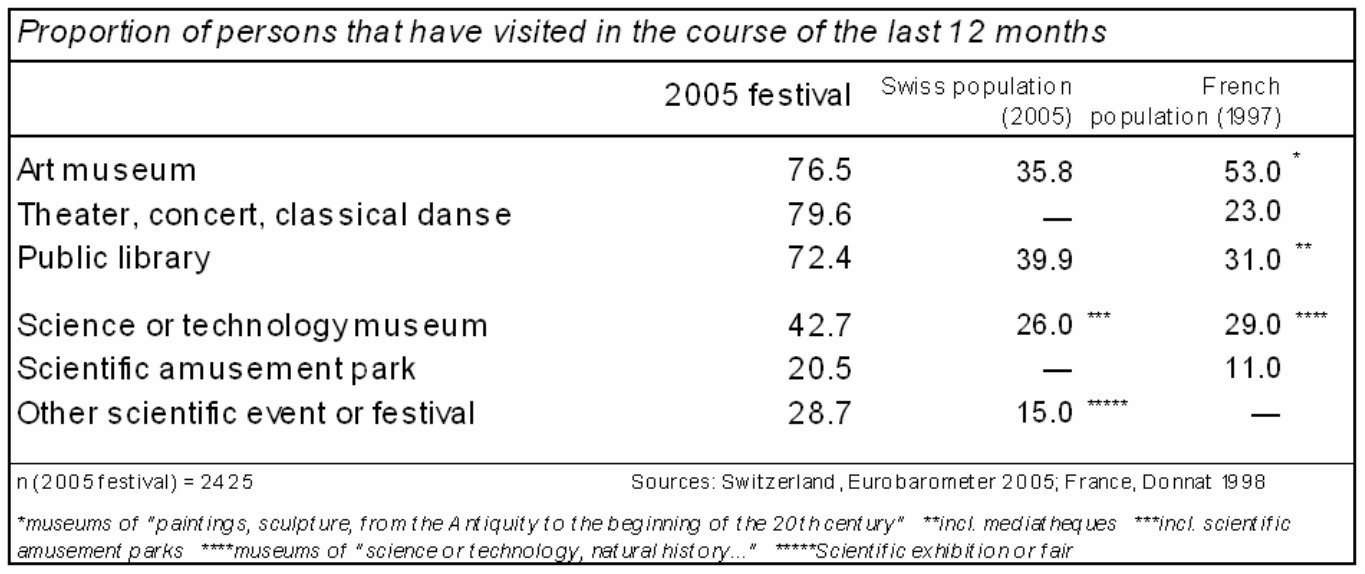

Table 2. Cultural practises of the festival's visitors (in \%).

The answers given by the festival goers to questions about their other cultural practises confirm that this public regularly frequents cultural institutions (table 2). Three quarters of the visitors declared having attended a museum of art in the year preceding the festival; in comparison this rate is a third in the Swiss population (and approximately half of the people in France). In the same way, not less than eight people out of ten indicated having recently attended a theatre, traditional concert or a dance performance; whereas in France, this percentage lies below a quarter of the population. The frequenting of public libraries by the festival-going public is also much higher than the national average. One notes finally that the festival goers attended scientific institutions or events more than the average population. To summarize, the combination of arts with science appealed to a public already interested in art and in science.

The 2005 Science et Cité festival, whose ambition was to speak to "the person in the street", thus attracted a relatively exclusive public. The idea of the connection with art only partially made it possible to appeal to a new public for science - namely that of women. Research on cultural practices reminds us regularly that the public of culture is feminised, in particular as regards art in its more traditional forms, some authors speaking even about an increased feminisation of cultural practices. ${ }^{22}$ For the rest, and in particular as regards age and education, the collaboration of the festival with art and artists did not bring its hoped for widening of the audience. 


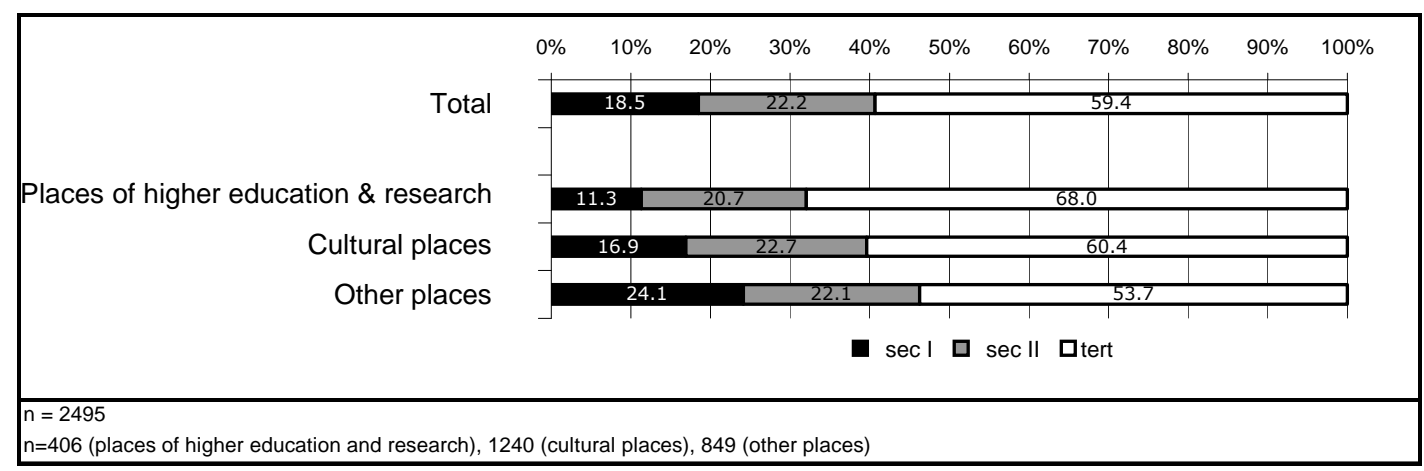

Graphic 1. Level of education of the festival's visitors, by type of place (in \%).

\section{The "spirit of the places" or the force of cultural institutions}

More than the sometimes avant-gardist side of the works presented during the festival, the very limited capacity of the festival to attract a large audience can be tied up with what could be called "the spirit of the places". A great part of the events of this festival - which wanted to be outside the places of knowledge production - took place between the walls of cultural institutions, also required for practical reasons. However, studies on cultural frequentation recall regularly that they are only little, if ever, attended by a majority of the population. The results of the survey show that half of the visitors already went before in the venues of the festival, the majority of them even several times.

The few public places used by the festival (public places, hospital, libraries, etc. - gathered under "other places") have better succeeded in attracting a public of modest or average education (graphic 1). Cultural institutions (and, in this case even more, places of higher education and research: Universities, Federal Institutes of Technology, Schools of Art, etc.), have, unsurprisingly, attracted a more exclusive public.

It would be interesting to be able to distinguish the container - the place or institution - from the contents (the play acted, the work exhibited, etc). Although the analysis of a singular event of the festival is somewhat risky considering the number of respondents concerned on this level, one can see that it tends to confirm that when an event is held in a legitimate institution - even if it is conceived as popular - it will tend to be attended by a rather exclusive public; on the contrary, a production with avant-gardist content, if it takes place in an institution usually visited by the broader population, will have a less exclusive public. $^{23}$

Ultimately, the types of places - their degree of legitimacy and their distance from the population determined the demographic make-up of the public attending the event. By its collaboration with art and artists - which has, still today, a highly distinctive social value - the promoters of the festival had not made the task easy. By preferentially using the established cultural institutions, they took the option (and the risk!) to localise part of the events of the festival in already existing practices of frequentation.

\section{Visitors' motives: art versus science}

Which were the motives of the festival visitors? The results of the survey state that the public went for various motives: in first position (graphic 2), one finds the option "to be informed, to learn something" (40\%), at equality with "by general interest for science". The theme of the festival (conscience) comes in second position (33\%), followed by "the link with my or relatives' work" (31\%), "by interest for the artistic side" (24\%) and "to occupy my leisure, to divert me" (17\%). If the objectives of the festival were to dialogue or to allow the public to influence the scientists, these objectives encounter very little the motives of the visitors ( $7 \%$ and $2 \%$ ).

Precisely, the "interest for the artistic side" only comes at the fifth position, with only one quarter of the visitors (24\%). The Science et Cité festival strives to be "a festival of the sciences and arts" for meeting civil society but the results show that this aim was difficult to achieve. In fact, the public went to the various events of the festival by interest either for its artistic or for its scientific component, seldom for both (graphic 3). 


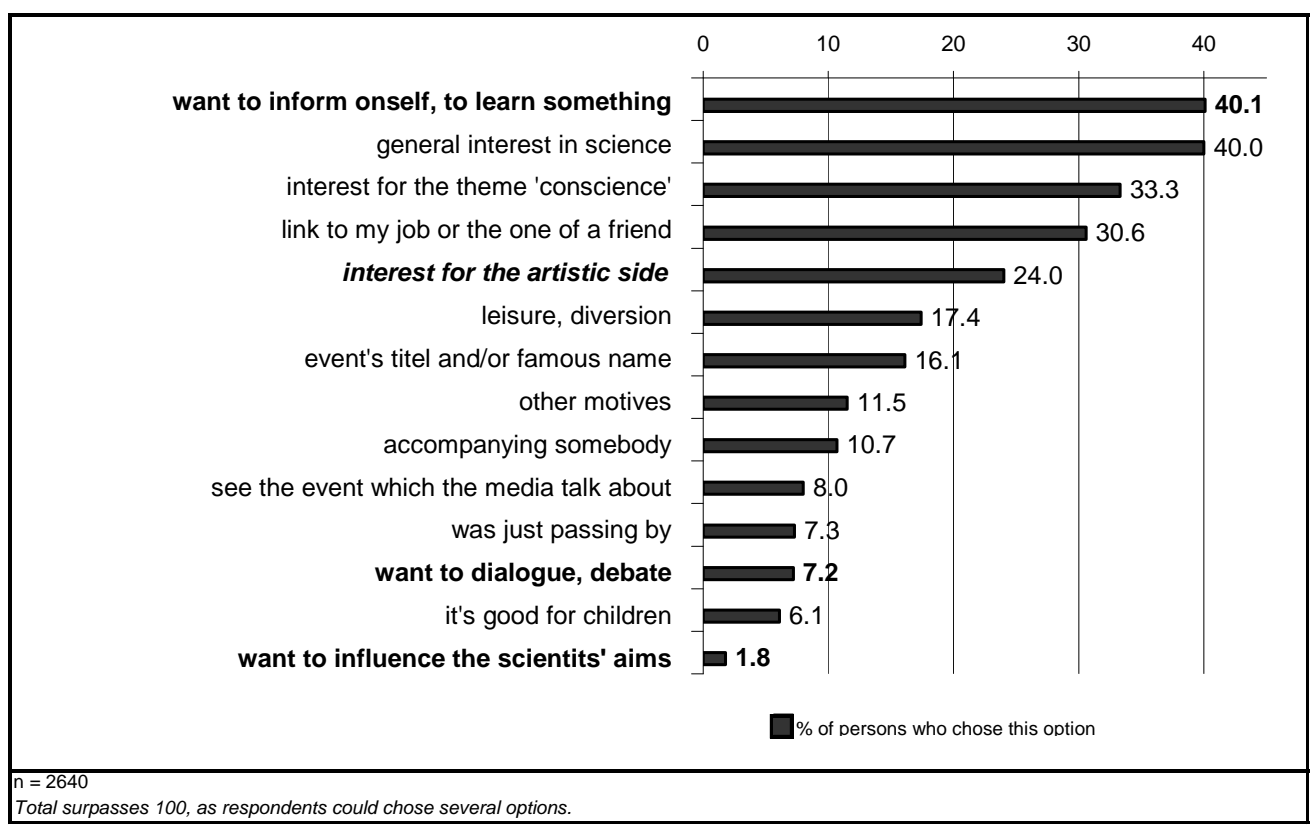

Graphic 2. Visitors' motives (in \%).

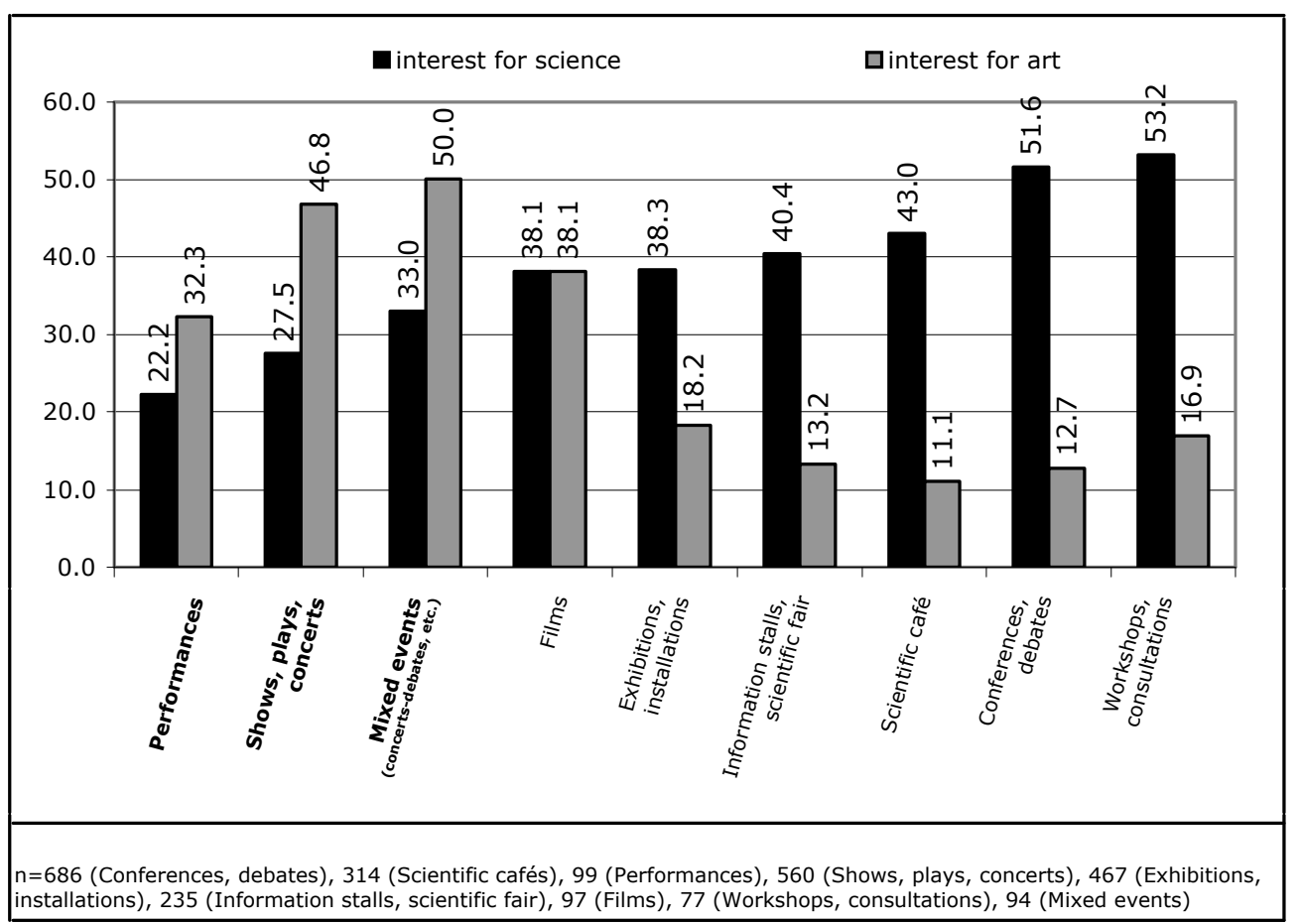

Graphic 3. Visitors' motives science / art, by type of event (in \%).

The more artistic events, such as performances, shows, plays and concerts, as well as "mixed events" (evenings with concert-debates, etc.), were attended by people with a mainly artistic interest. Conversely, information stalls and scientific fairs of course, scientific cafés, conferences and debates, workshops and scientific consultations, but also exhibitions and installations, attracted an audience more interested in science. In spite of the objective of the festival to make science and art collaborate, the visitors' motives were thus finally rather distinct in this respect. 


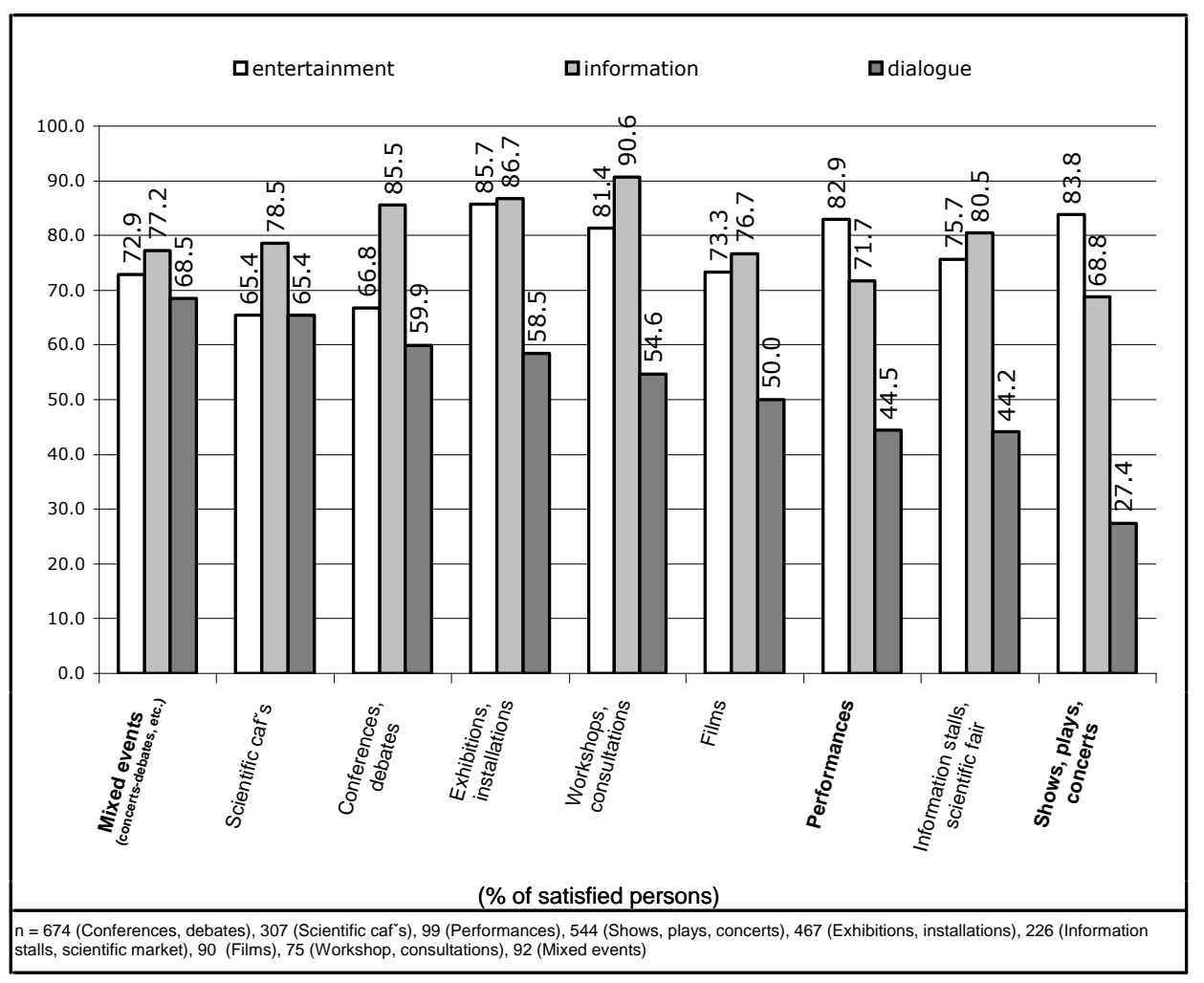

Graphic 4. Visitors' satisfaction with the attended event of the festival.

Art, a dialogical mediation?

The general figures of the Science et Cité festival indicate a very high rate of overall satisfaction on the side of the visitors ( $97 \%$ of respondents say they were "very or rather satisfied" with the event). Moreover, a majority of the visitors was satisfied with the possibility of learning something (80\%), of asking questions (57\%), of dialoguing with the scientists $(51 \%)$ or - less clearly - of influencing scientists $(15 \%)$.

If art unquestionably brought an aesthetic and entertaining dimension, even sometimes an apposite "critical perspective" ${ }^{24}$ within this scientific event, it did not, at the same time, always contribute to the science-society dialogue. This was suggested by the degree of satisfaction the visitors expressed with the quality of the science-society exchange during the attended event (graphic 4, classified by descending order according to satisfaction with the possibility of dialogue with the scientists).

The events that were more properly artistic collected many votes as regards the possibility of diverting and entertaining oneself, even also for getting information; on the other hand, the possibility of a dialogue or of a discussion was often considered to be less satisfactory by the visitors in these events (which are rather in the second half of the graphic). In contrast, the more traditional events of scientific communication like the scientific cafés or the conferences and grand debates provided a greater opportunity for dialogue. In fact, the "mixed events" (evenings with concert-debates around sets of themes, conferences followed by performances, etc.), as a very thorough scientific-artistic hybrid mediation, achieved the highest scores in terms of providing entertainment, information or dialogue.

The results also showed that if the assessment of alliance with art is at first sight rather positive, the detailed analysis reveals some zones of shade in this relatively harmonious picture. Indeed, nearly three quarters of the visitors considered that the inclusion of art in the festival was an asset for the public (graphic 5). However, this indicates global satisfaction with the inclusion of art, but not if the public learned more about science in the combination than in event without art (which could only be established with an experimental design study). 


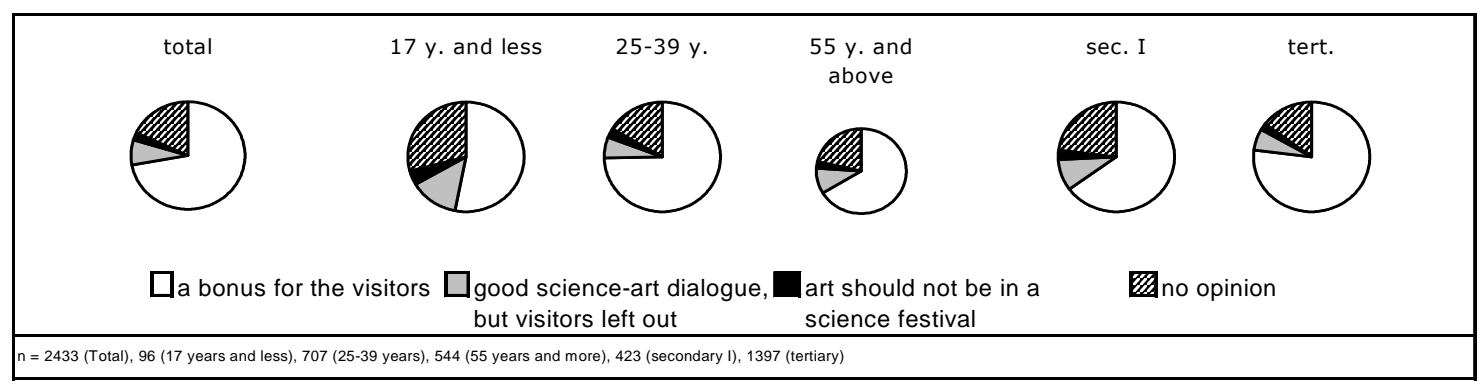

Graphic 5. Visitors' opinion on collaboration with art (in\%).

Young people were less enthusiastic on collaboration with art, as were people aged over 55 - which related to the difficult accessibility and sometimes trendy side of the works shown during the festival. If $77 \%$ of the university visitors approved the resort to art in the festival, only $67 \%$ thought it among the non-academics - but the question was addressed to the public of the event, which was already rather benevolent in this respect. Finally, one notes without surprise that women appreciated the contribution of art slightly more; men agreed slightly more that the public was forgotten, even that art should not appear in an event like that.

\section{Conclusions and discussion}

Over the past 50 years science and technology have changed every aspect of our lives, from health to work or even society. In this context, communication between science and society should lean on every effective type of mediation. Artistic mediation has been promulgated because art involves people emotionally, and activates processes of participation and dialogue. ${ }^{25}$ In the 2005 Science et Cité festival, art was meant to play the role of mediator between science and society. Two dangers threatened the promoters of this idea. First as regards the art and science collaboration: the philosopher Lévy-Leblond has evoked the "double misunderstanding" which often characterises the interactions between these two worlds, the artists imagining a solitary researcher and the scientists seeing only the public dimension and media coverage of art. According to this author, "when there is an encounter, the dialogue practically does not take place". ${ }^{26}$ The danger, concerning the audience, is that even if sociological research on cultural practices has recently shown a relative diversification of the access modes to culture and of cultural products themselves, ${ }^{27}$ the effect of the "distinction" of the consumption of art, as described by Pierre Bourdieu at the end of the 1970 s, is without any doubt still topical. ${ }^{28}$

Behind the high level of satisfaction with the event among visitors - and, in particular, with the resort to art - lies an exchange whose ambivalence and contradictions were revealed by the analysis of the practices and the representations of the participants. The analysis revealed that the audience was a little bit older and more educated than the national average, but also more feminised, as it was largely a cultural public. On that specific point and in agreement with the general findings of research - which describes in a recurring way the high degree of feminisation of the cultural public - the promoters' wish to reach a new public for science undoubtedly succeeded. The study also showed that the motives of the visitors were very diverse as regards interest in the relation art-science or in informing the public on scientific contents. If the event has been, without any doubt, successful in attracting a new audience, one should rather speak of a widening of the scientific interest on the side of the cultured public, relatively close to the academic circles, than of a true democratization.

More than the connection with art, it is especially the localisation of this last manifestation of the festival in cultural institutions which is in question. The problem of the connotation of the places was already raised in the literature: some recall that the expectations and the reactions of the public are "significantly influenced by the nature of the venues" in which the events take place; ${ }^{29}$ others advise the use of museums, shopping centres, even town halls, considered by the population as "neutral". ${ }^{30}$ Without the love of art there is no dialogue with science, seemed to say the promoters of the Science et Cité festival. In fact, in some of its events, science above all dialogued with art and its public, less with the general public. The setting of the festival has thus, in certain cases, condemned the visitor to be only the 
spectator of the debates between scientists and artists. However, the PUS handbooks and the recent studies in scientific museology defend the idea of an active visitor, who should not be considered as a "tabula rasa" but as a "social subject", who builds his own exhibition. ${ }^{31}$ From this point of view, the festival could convey less to an "understanding" than to a "celebrating of science".

In the end, it is however important to note that the majority of the visitors saluted not only the idea of a collaboration with art and artists, but, what is more, they wished that this exchange should continue. In addition, some of the results of the study indicated that the visitors of the event would have wished the festival to be based more on "ethics", meaning that they expected a more critical view of the evolution of science - art probably could (and certainly should) have played that part in the festival.

In other words, the place of art in the science-society dialogue must be put under scrutiny. For some authors, science and art are integrated "in a network of social and political relations which sociology has termed contextualization". ${ }^{32}$ The comprehension of the "many misunderstandings" which characterise the exchanges between scientists and citizens ${ }^{33}$ - and artists, one could say - should allow to better target the efforts of scientific communication towards a large audience through art. The potential of art within the framework of the "new contract" suggested between science and the civil society ${ }^{34}$ is obvious; in this respect, art could even play a central role.

\section{Notes and references}

${ }^{1}$ J. Gregory and S. Miller, Science in Public. Communication, Culture, and Credibility, New York, Plenum Trade, 1988. M. Bucchi, La Scienza in Pubblico, Milan, Mc Graw-Hill, 2000. P. Greco, "Understanding Publics of Science", JCOM 5(1) 2003. Retrieved Nov 2, 2005; available at: <http://jcom.sissa.it/archive/02/01/E0201/>

${ }^{2}$ See the review of J. Nolin, F. Bragesjö and D. Kasperowski, Science Festivals and Weeks as Spaces for OPUS, in: U. Felt (ed), Optimising Public Understanding of Science and Technology: Final Report, Vienna, University of Vienna, 2003, p. 271-282. Retrieved April 6, 2007; available at: 〈http://www.univie.ac.at/virusss/opus/OPUS Report Final.pdf>

${ }^{3}$ For "Public Understanding of Science".

${ }^{4}$ B. Wynne, Public Understanding of Science, in: S. Jasanoff, et al. (eds), Handbook of Science and Technology Studies, Thousand Oaks/London/New Dehli, Sage, 1995, p. 361-388.

${ }^{5}$ Research International, Science and the public: mapping science communications activities, Research International, London, 2000. Retrieved April 6, 2007; available at: 〈http://www.wellcome.ac.uk/assets/wtd003418.pdf>

${ }^{6}$ M. Callon, Des Différentes Formes de Démocratie Technique, Les Cahiers de la Sécurité Intérieure, 38, 1999, p. 35-52.

${ }^{7}$ D. Raichvarg and J. Jacques, Savants et Ignorants. Une Histoire de la Vulgarisation des Sciences, Paris, Seuil, 1991. Wellcome Trust, Refreshing Art: Reaching the Parts Science Doesn't Reach, Wellcome News, 3, 2002, p. 22-23.

${ }^{8}$ A. Drioli, "Contemporary Aesthetic Forms and Scientific Museology", JCOM 5(1) 2006. Retrieved Dec 2, 2006; available at: <http://jcom.sissa.it/archive/05/01/A050102/>

${ }^{9}$ E. Abadi, Des usages de l'art dans l'exposition scientifique. L'expérience de la Cité des Sciences et de l'Industrie, Paris, DESS (1999).

${ }^{10}$ P. Bourdieu, La Distinction. Critique Sociale du Jugement, Paris, Ed. de Minuit (1979).

${ }^{11}$ O. Donnat, Les Pratiques Culturelles des Français. Enquête 1997, Paris, La Documentation Française (1998).

${ }^{12}$ P.B., "Ask the Audience. How Do Visitors React to Science and Art", Wellcome News, 1, 2004, p. 8-9.

13 A. Drioli.

${ }^{14}$ J.-M. Lévy-Leblond, “La Science et le Monde, l'Art et Moi”, RTD-Info, nº spécial, March 2004, p. 5-7.

${ }^{15}$ S. Webster, Art, Science and the Public, in: Wellcome Trust (ed), Engaging Science: Thoughts, Deeds, Analysis and Action, London, Wellcome Trust, 2006, p. 74-79.

${ }^{16}$ The fist edition took place in 2001 around the general theme of science-society interaction with standard scientific mediation.

17 The quotations concerning the Foundation and the festival are drawn from their Internet site available at <www.science-etcité.ch> and <www.science-et-cite.ch/projekte/festival/festival2005/fr.aspx>

${ }^{18}$ For example the plays "Der Mitmacher" (the collaborator) from F. Dürrenmatt and "Antigone" from Sophocle or the movies The Island of Dr. Moreau, from D. Taylor and One Flew Over the Cuckoo's Nest, from M. Forman.

${ }^{19}$ For example Trip inside the head, from Collectif Nunc, a play that think about madness, psychiatry and neurosciences with testimonies of specialists as well as of concerned people; How to measure the height of a building with a barometer?, from Ateliers du Capricorne, a duet-comic around this historical experience; Cellar with conscience, a choreographic creation from the company Da Motus, to discover our memory and to reflect on the psychosis.

${ }^{20}$ We followed the model suggested by Ulrike Felt in her studies of Science Weeks in Austria with a survey among the visitors and a survey among the organisers (U. Felt, Evaluierung der ScienceWeek @ Austria 2002, Vienna, University of Vienna, November 2002). This paper includes only results from the visitors' side. The whole report : O. Moeschler, F. Crettaz von Roten and J.-Ph. Leresche, Une 'Fête des Sciences et des Arts' pour un Dialogue entre la Science et la Société ? Rapport final, is available on the Internet <www.unil.ch/osps> and the main results are reported in O. Moeschler and F. Crettaz von Roten, "Un Festival des Sciences et des Arts pour un Dialogue Science-Société : Regards Croisés des Organisateurs et des Visiteurs". In: J.-Ph. Leresche, et al. (eds), La Fabrique des Sciences. Des Institutions aux Pratiques, Lausanne, PPUR, 2006, p. 305-327. 
${ }^{21}$ Results from the evaluation of the 2001 festival in Lausanne can be found in P. Hof, F. Crettaz de Roten, M. Merz and J.-Ph. Leresche, Etude évaluative de la partie lausannoise du Festival Science et Cité. Rapport final, Lausanne, OSPS-EFPL, 2001. Available at <http:// www.unil.ch/osps〉. It should be noted that the 2005 survey did not include - in the same manner as the 2001 study - the visitors of less than 15 years, present in a limited number of events of the festival.

${ }^{22}$ O. Donnat, La Féminisation des Pratiques Culturelles, Développement Culturel 147 (2005) 1.

${ }^{23}$ Thus a light comedy and an avant-gardist production played on an established scene in Zürich attracted a large proportion of academics, approximately six people out of ten. Conversely, performances that were potentially more demanding put on in more accessible places (e.g. in a Museum of nature, the cafeteria of a central public library or a historical building well known to the population) attracted a much less exclusive public, with sometimes more than half of the visitors with average or modest education.

${ }^{24}$ J. Davallon, Les Musées de Sciences et leurs Publics, entre Communication et Médiation, in: B. Pellegrini (ed), Sciences au Musée, Sciences Nomades, Geneva, Georg Editeur, 2003 p. 183-198.

${ }^{25}$ A. Drioli.

${ }^{26}$ J.-M. Lévy-Leblond, p. 5.

${ }^{27}$ O. Donnat, Les Français Face à la Culture. De l'Exclusion à l'Eclectisme, Paris, La Découverte, 1994. B. Lahire, La Culture des Individus. Dissonances Culturelles et Distinction de Soi, Paris, La Découverte, 2004.

${ }^{28}$ P. Bourdieu.

${ }^{29}$ P. B.

${ }^{30}$ R. Miles and A. Tout, Exhibitors and the Public Understanding of Science, in: J. Durant (ed), Museums and the Public Understanding of Science, London, Science Museum, 1992, p. 27-33. L. Grant, Evaluation of the 2003 Cheltenham Festival of Science, Liverpool, University of Liverpool, 2003. Research Councils, Dialogue with the public. Practical guidelines, London, Research Council UK and the Office of Science and Technology, 2002.

${ }^{31}$ J. Davallon, p. 194.

${ }^{32}$ G. Kreutzberg, Scientists and the Marketplace of Opinions, EMBO Reports 6(5) (2005) 393.

${ }^{33}$ U. Felt and A. Müller, Science Week and Festivals in Austria: an Experiment in Science Communication, in: U. Felt (ed), Optimising Public Understanding of Science and Technology: Final Report, Vienna, University of Vienna, 2003, p. 283-286. Retrieved April 6, 2007; available at: <http://www.univie.ac.at/virusss/opus/OPUS Report Final.pdf>

${ }^{34}$ H. Nowotny, P. Scott, and M. Gibbons, Repenser la science. Savoir et société à l'ère de l'incertitude, Paris, Belin (2003).

\section{Authors}

Fabienne Crettaz von Roten is senior scientist, head of research unit «Relations science-société » at the Observatoire Science, Politique et Societé, University of Lausanne, Switzerland. She performs research on the attitudes and perceptions of the Swiss population toward science and technology.

E-mail: Fabienne.CrettazVonRoten@unil.ch.

Olivier Moeschler is sociologist and researcher at the Observatoire Science, Politique et Societé, University of Lausanne, Switzerland. He mostly works in the field of sociology of cultural sociology and sociology of the arts. E-Mail : Olivier.Moeschler@unil.ch. 